\title{
A Study of Caffeine Level Changes, Fat and Water in Arabica Coffee Due to the Attack of Coffee Borer Pests (Hyphothenemus Hampei)
}

\author{
Olyfia Rosalina ${ }^{1}$, Muhammad Sayuthi ${ }^{2}$, Rita Hayati ${ }^{2}$ \\ ${ }^{1}$ Master Student at Agroecotechnology Department, Agriculture Faculty, Syiah Kuala University, Indonesia \\ ${ }^{2}$ Agriculture Faculty, Syiah Kuala University, Indonesia
}

\begin{abstract}
Coffee borer beetles (Hyphothenemus hampei) generally bore the coffee fruit which its endosperm has already hardened, and thenthere is a disability at coffee bean causing a damage of chemical quality, while the flavor of coffee is influenced by combination of chemical compound components contained in the coffee bean. This study aims to see the changes in levels of caffeine, fat and water in coffee due to the attack of coffee borer beetle (H. hampei). The levels test of caffeine, fat and coffee water were carried out in the laboratory of Baristan Aceh and the farm laboratory of agriculture faculty of Syiah Kuala University. The results of the test show that $H$. hampei pests can cause the increase of caffeine level in the coffee beans up to $1.41 \%$, decrease of fat level in the coffee beans up to 15,81\% and the increase of water level in the coffee bean up to $2.58 \%$.
\end{abstract}

Keywords: caffeine level, fat level, water level, Hyphothenemus Hampei.

\section{Introduction}

Coffee is one of the leading commodities with high economic value in the world market, the demand keeps increasing from time to time because coffee has unique characteristics such as robusta coffee which has the advantage in terms of shape and arabica coffee is superior in terms of its distinctive taste (Yusianto, 2008). Rahardjo (2012) also explains that coffee is one of the plantation commodities that have high economic value among other plantation crops and play an important role as a source of foreign exchange which is also a source of income for one and more than a half million coffee farmers in Indonesia.In the seventeenth century the spread of coffee crops to Indonesia was brought by the Dutch aristocrats around 1646 who obtained Arabica beans from Arabia but this plant died from floods. In 1699 the new seeds were brought back which then developed around Jakarta and West Java and eventually spread to various parts of the Indonesian archipelago (Gandul, 2010).

In Indonesia, the best coffee producer is found in Aceh Province precisely in Gayo Highlands supported by geographical area which is suitable for coffee plantation. Currently the area of Arabica coffee in this region reaches more than 90,000 ha. Coffee cultivation is generally done by local farmers and is a source of their livelihood (Ramadhan, 2011).H. hampeiinsects come into the coffee fruit by making a hole in the tip of the fruit around the discus, causing fruits damaged and fall. The physical damage caused by PBKo pests also affects the taste of coffee. The defects of coffee beans such as holed coffee will cause flaws taste smoky, earthy, musty and chemical (Kirom, 2005).The purpose of this study is to determine the changes in caffeine, fat and water levels in arabica coffee due to the attack of coffee borer beetle (Hyphothenemus Hampei). The results obtained are important information for the coffee farmers and entrepreneurs.

\section{Research Method}

This research was carried out at Farming Laboratory of Agriculture Faculty of ShiahKuala University and Baristan Aceh Laboratory. The material used in this research is Arabica coffee with two samples, namely the quality of coffee beans I (which is not defective due to $H$. hampei pest) quality II (defect caused $H$. hampeipest attack).

\subsection{Caffeine Test}

The equipment used: HPLC, analytical scales, agitator, paper filter cone Whatman no 1, water bath; vacuum filter (pore size: $0.45 \mu \mathrm{m}, 13 \mathrm{~mm}$ diameter), membrane filter, $100 \mathrm{ml}$ erlenmeyer glass, $100 \mathrm{ml}$ cup glass, $500 \mathrm{ml}$ measuring flask, $250 \mathrm{ml}$ measuring flask, $100 \mathrm{ml}$ measuring flask, $50 \mathrm{ml}$ measuring flask, syringe with filter membrane (pore size: $0.4 \mu \mathrm{m}, 13 \mathrm{~mm}$ diameter), reaction tube, $50 \mu 1$ syringe.

The reactor: $\mathrm{Pb}$ acetate, $\mathrm{PbO}$, Aquadest, aquadest filter, standard caffeine (brand), ethanol absolute, methanol (grade gradient for liquid chromatography). 
a. Preparation of aquadest filter: the aquadets filter uses a filter vacuum with filter membrane (pore size: 0.45 $\mu \mathrm{m}, 47 \mathrm{~mm}$ diameter)

b. Preparation of main liquor

- Weigh carefully the caffeine standard of $0.125 \mathrm{~g}$.

- Dissolve with absolute ethanol: aquadest filter (1: 4) into a $250 \mathrm{ml}$ measuring flask and put on the line.

c. Preparation of standard solution

- the Pipette of each $2 \mathrm{ml}, 5 \mathrm{ml}$, and $10 \mathrm{ml}$ standard main solution into a $50 \mathrm{ml}$ measuring flask.

- Then add with aquadest filter until the line marks.

d. Preparation of $\mathrm{Pb}$-acetate solution

- Weigh $115 \mathrm{~g}$ of acetate and $60 \mathrm{~g} \mathrm{PbO}$.

- Dissolve with aquadest in a $500 \mathrm{ml}$ measuring flask until all $\mathrm{PbO}$ dissolves and creates a cloudy white solution.

- Apply with aquadest until the line marks.

e. Preparation of test solution

- Weigh $+1 \mathrm{~g}$ of coffee powder sample into a $100 \mathrm{ml}$ erlenmeyer.

- Dissolve with $+40 \mathrm{ml}$ of aquadest, add $1 \mathrm{ml}$ of acetate $\mathrm{Pb}$.

- Heat in a water bath at $100^{\circ} \mathrm{C}$ for 15 minutes, then cool at room temperature

- Move into the $100 \mathrm{ml}$ flask with a funnel and rinse the erlenmeyer with aquades at least 3 times, then apply it to the line mark, then filter with filter paper of Whatman No.1 into a 100ml cup glass.

- 10ml pipette of filtrate into $50 \mathrm{ml}$ measuring flask, add aquades until the line marks.

- Then filter the filtrate using syringe with membrane filter (pore size: $0.45 \mu \mathrm{m}, 13 \mathrm{~mm}$ diameter) into the test tube.

f. Preparation of mobile phase

- Solvent used as mobile phase for checking caffeine content with HPLC tool is 70\% aquadest filter and 30\% methanol (gradient grade for liquid chromatography).

- Solvent should be filtered first using a vacuum filter with membrane filter (pore size: $0.45 \mu \mathrm{m}, 47 \mathrm{~mm}$ in diameter) before being used for inspection.

g. Procedure

Both standard and test solutions of $10 \mu 1$ were injected by $50 \mu 1$ syringe to HPLC device, where the condition of HPLC tool at the time of analysis:

$\begin{array}{ll}\text { Column } & : \text { Hypersil ODS C } 18.5 \mathrm{UM}, 100 \times 4.6 \mathrm{~mm} \\ \text { Mobile phase } & : \text { Aquadest filter; Methanol }(70 \%: 30 \%) \\ \text { Flow rate } & : 0.75 \mathrm{ml} / \text { min Temperature: } 35^{\circ} \mathrm{C} \\ \text { Detector } & : \text { VWD with UV } 272 \mathrm{~nm}\end{array}$

h. Result statement

The caffeine level of the sample was obtained from a comparison of standard chromatography with the sample chromatography obtained.

\subsection{Fat Level Test}

There are three ways to do this:

The first involves grinding up the food and mixing it with water. Pass the liquid part of the solution through filter paper, squeezing out any 'gunge' - thick bits of the suspension into the same test tube. You should now have a slightly opaque liquid mixture in your test tube. Because fat is less dense than water, if you leave this mixture it will separate out into a layer of fat and a layer of water. The second test is even easier. Rub the food sample on filter paper and then hold the filter paper up to the light. If the paper is translucent (slightly seethrough) there was fat present in the food. Don't try this with watery foods - the water will make the paper translucent and you'll get a false positive. The third method involves adding ethanol to a very small amount of the test substance. Shake or crush the food to make it dissolve. Filter or dilute the food and ethanol mix so that you get a clear liquid (a solution of fat in ethanol). Add this to a test tube of water. A white (milk-like) emulsion indicates the presence of fats or oils.

\subsection{Water Level Test}

One of the factors that affect the drying process is the level water. Drying aims to reduce the water content of the ingredients inhibits the development of decay organisms. Water content of a material affect the amount of water vaporized and the length of the process drying (Taib et al., 1988). The water content of a material is the amount of water content of unity the weight of the material expressed in a wet base basis or in percent dry basis. Wet basin moisture content has theoretical maximum limit of $100 \%$, while the base water content is dry more $100 \%$. Moisture base water content $(\mathrm{Mwb})$ is the ratio between weight water present in the material with the total weight of the material. The structure of materials in general can be based on moisture 
content usually indicated in the percentage of water content of wet or base basis dry. Moisture base water content $(\mathrm{Mwb})$ is widely used in the determination the market price while the dry base water content (Mdb) is used in the field technique (Brooker et al., 1974). The equation in the determination of moisture content

$\mathrm{Mdb}$ $=.$.

Description: $\mathrm{Mdb}=$ dry base water content $(\%)$

$\mathrm{Wt} \quad=$ total weight $($ gram $)$

$\mathrm{Wd} \quad$ = solid weight $($ gram $)$

Mwb

$=$

Description: $\mathrm{Mwb}=$ moist base moisture content $(\%)$

$\mathrm{Wt} \quad=$ total weight $($ gram $)$

$\mathrm{Wd} \quad=$ solid weight $($ gram $)$

Determination method of water content can be done in two ways, namely direct methods and indirect methods

Direct methods apply oven method and distillation method. In the oven method, the material sample put into the oven to obtain a constant weight on the material. The determination of moisture content in oven method is based on the amount of water that is lost from the product. As for the method of distillation, water content is removed by heating the seeds into water and then determining the volume or the mass of water lost to the seed in a condensed or vapor with a reduction in sample weight (Brooker et al., 1974).

\section{Caffeine Levels}

\section{Results And Discussion}

One of the compounds contained in coffee is caffeine. Caffeine is one type of alkaloids that are mostly found in coffee beans (Aryanu, 2016). Caffeine content in coffee besides giving the negative impact on humans, it also provides a positive impact. The coffee is used as a lung capacity enhancer in patients asthmabronchial, Rahayu (2007). Coffeefag (2001), also describes that caffeine has a clinically beneficial pharmacological effect, such as stimulating central nervous system, smooth muscle relaxation, especially bronchial smooth muscle and heart muscle stimulation. The harmful thing is when the levels of caffeine in coffee are too high. The excessive (over dose) effects of caffeine can cause nervousness, anxiety, tremors, insomnia, hypertension, nausea and seizures (Pharmacology UI, 2002).Based on the percentage analysis of caffeine level in coffee beans, it showed that the attack of $H$. hampei pest can cause the increased levels of caffeine in coffee beans. The average percentage of caffeine level of coffee beans after tested can be seen in Figure 1.

Figure. 1 Level Percentage of Coffee Caffeine

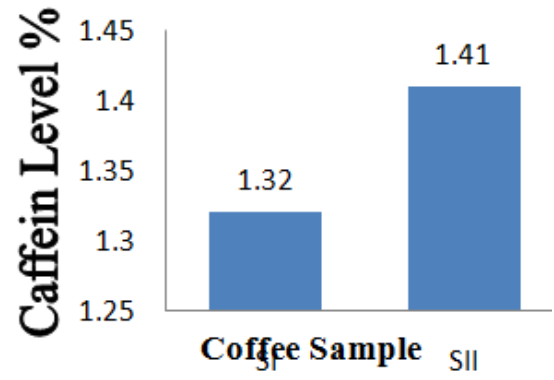

The figure above shows that, caffeine content of coffee beans attacked by H. hampei(S II) is higher than caffeine content of coffee beans that are not attacked by $H$. hampei(S I). The combination of chemical compounds contained in coffee beans greatly affect the taste of coffee while the H. hampeiattack can cause defective coffee beans and also negatively affect the composition of chemical compounds contained in coffee beans, especially in caffeine and reducing sugar (Tobing Et al., 2006). H. hampei is one of the main causes of declining production and quality of coffee in Indonesia, even in all coffee-producing countries. The resulting damage to the fruit is the fruits become undeveloped, they turn reddish yellow and eventually fall resulting in a decrease in the number and quality of results (Hayata, 2016).

\section{Fat Level}

Based on the analysis of fat ;eve; percentage of coffee beans showed that the attack of $H$. hampeipest can cause decreased fat level in coffee beans. The average percentage of fat level of coffee beans after tested can be seen in figure 2 . 
Figure. 2 Level Percentage of Coffee Beans Fat

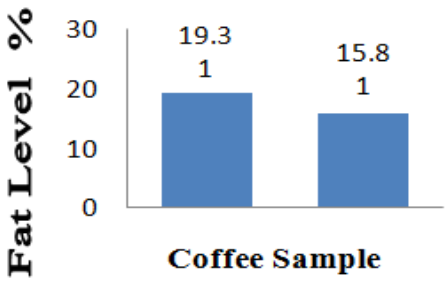

The figure above shows that the fat level of coffee beans attacked by H.hampei (S II) is lower than the fat content of coffee beans that are not attacked by H. hampei (S I). H. hampei gets into the coffee fruit by making a hole around the discus, which causes the young coffee fruits to fall and disability in the old coffee fruit this resulted in the quality of the resulting coffee (PPKKI, 2006). The losses caused by the attack of H. hampei become more significant because besides directly reduces the physical production, it also decreases the quality resulting in decreased price of coffee beans produced (Yahmadi, 2000).

\section{Water Level}

Based on the analysis of water level percentage of coffee beans, it showed that the attack of $H$. hampei pest can cause the increasing water level in coffee beans. The average percentage of water level of coffee beans after tested can be seen in Figure 3

Figure. 3

Water LevelPercentage of Coffee Beans

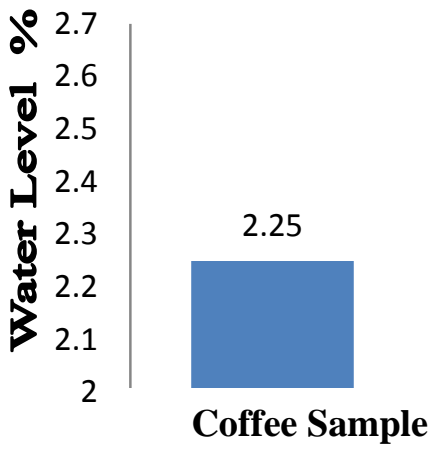

2.58

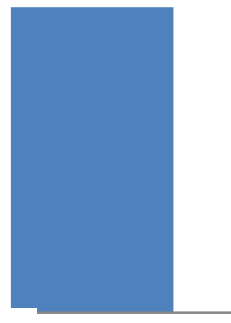

SII

The picture above shows that, the water level of cottee beans attacked by H.nampei (S II) is higher than the water content of coffee beans that are not attacked by H.hampei ((S I). The severe damage can occur when the coffee hardened, because in addition to drilling and eating coffee beans, this beetle also breeds in the seeds so that the beans are deformed and perforated so that the coffee produced is a low quality market coffee with the damage it can cause Reaching 30 - $80 \%$ of production (Juneanto, 2000).

\section{Conclusion}

The test results obtained that the attack of $H$. hampei pest can cause the increased levels of caffeine in coffee beans, the decreased levels of fat in coffee beans and the increased water level in coffee beans.

\section{References}

[1] Aryanu, F. A., Ida, A. R. A. A., I Wayan, S. (2010). Analisis Kandungan Kafein Pada Kopi Di Desa Sesaot Narmada Menggunakan Spektrofotometri Uv-Vis. Jurnal Kimia 10 (1), Januari 2016: 110-114

[2] Brooker, D. B., F. W. Bakker-arkema and C. W. Hall, 1974. Drying Cereal Grains. The AVI publishing Company, Inc. Wesport. Ciptadi, W. dan Nasution, M.Z. 1985. Pengolahan Kopi. Fakultas Teknologi

[3] Coffefag.(2001).Frequently Asked Questions about Caffeine, www.Coffefag.com, Diakses 26 Maret 2013

[4] Farmakologi,U.I. (2002). Farmakologi dan Terapi, 4th ed, Gaya Baru , Jakarta

[5] Gandul. (2010). Sejarah Kopi. http://sekilap.blog.com/ 2010/ 01/05/sejarah-kopi/diunduh 22 juli 2010. Posted by ajhiin Jan 05, 2010

[6] Junianto, Y.D. (2000). Penggunaan Beauveria bassiana untuk pengendalian hama tanaman kopi dan kakao. Workshop Nasional Pengendalian Hayati OPT Tanaman Perkebunan, Cipayung, 15-17 Februari 2000. Balai Penelitian Kopi dan Kakao, Jember. 15 hlm.

[7] Kirom, M. (2005). Nikmat kopi hilang karena cacat biji.Iptek/Kesehatan.Kopi Indonesia ,124, 25.

[8] PPKKI. (2006). Pusat Penelitian Kopi dan Kakao Indonesia. Pedoman Teknis Budi Daya Tanaman Kopi. Indonesia Coffee and Cacao Research Institute Jember, Jawa Timur

[9] Rahardjo. (2012). Panduan Budidaya dan Pengolahan Kopi Arabika dan Robusta. Penebar Swadaya. Jakarta

[10] Rahayu, T. \& Triastuti, R. (2007). Optimasi Fermentasi Cairan Kopi Dengan Inokulan Kultur Kombucha (Kombucha Coffee), Jurnal Penelitian Science dan Teknologi, 8 (1) : 15-29 
[11] Ramadhan, M. (2011). Faktor-faktor yang Mempengaruhi Produktifitas Petani Kopi di Kabupaten Aceh Tengah. Universitas Syiah Kuala, Banda Aceh.

[12] Taib, G., Gumbira Said, dan S. Wiraatmadja. 1988. Operasi Pengeringan pada Pengolahan Hasil Pertanian. PT Mediyatama Sarana Perkasa. Jakarta.

[13] Tobing, M.C., Bakti, D \& Marheni. (2006). Perbanyakan Beauveria bassiana pada beberapa media dan patogenisitasnya terhadap imago penggerek buah kopi Hypothenemus hampei Ferr. (Coleoptera: Scolytidae). Jurnal Agrikutura 17(1):30-35 (Terakreditasi).

[14] Yusianto. (2008). Panduan Budidaya dan Pengolahan Kopi Arabika Gayo. Indonesian Coffee and Cocoa Research Institute (ICRRI). Jember 